\title{
Periostin Is Induced in Glomerular Injury and Expressed de Novo in Interstitial Renal Fibrosis
}

\author{
Kontheari Sen, ${ }^{\star}$ Maja T. Lindenmeyer, ${ }^{\star \dagger}$ \\ Ariana Gaspert, ${ }^{\ddagger}$ Felix Eichinger, ${ }^{\S}$ \\ Matthias A. Neusser, ${ }^{\dagger}$ Matthias Kretzler, ${ }^{\S}$ \\ Stephan Segerer, ${ }^{\dagger \uparrow}$ and Clemens D. Cohen ${ }^{\star \dagger}$ \\ From the Institute of Physiology* and the Department of \\ Anatomy, ${ }^{\text {Tा }}$ University of Zurich, Zurich, Switzerland; the \\ Division of Nephrology ${ }^{\dagger}$ and the Institute of Surgical Pathology, \\ University Hospital Zurich, Zurich, Switzerland; and the \\ Department of Medicine, "University of Michigan, Ann Arbor, \\ Michigan
}

Matricellular proteins participate in the pathogenesis of chronic kidney diseases. We analyzed glomerular gene expression profiles from patients with proteinuric diseases to identify matricellular proteins contributing to the progression of human nephropathies. Several genes encoding matricellular proteins, such as $S P A R C, T H B S 1$, and CTGF, were induced in progressive nephropathies, but not in nonprogressive minimal-change disease. Periostin showed the highest induction, and its transcript levels correlated negatively with glomerular filtration rate in both glomerular and tubulointerstitial specimen. In well-preserved renal tissue, periostin localized to the glomerular tuft, the vascular pole, and along Bowman's capsule; no signal was detected in the tubulointerstitial compartment. Biopsies from patients with glomerulopathies and renal dysfunction showed enhanced periostin expression in the mesangium, tubular interstitium, and sites of fibrosis. Periostin staining correlated negatively with renal function. $\alpha$-smooth muscle actin-positive mesangial and interstitial cells localized close to periostin-positive sites, as indicated by co-immunofluorescence. In vitro stimulation of mesangial cells by external addition of TGF- $\beta 1$ resulted in robust induction of periostin. Addition of periostin to mesangial cells induced cell proliferation and decreased the number of cells expressing activated caspase-3, a marker of apoptosis. These human data indicate for the first time a role of periostin in glomerular and interstitial injury in acquired nephropathies. (Am J Pathol 2011, 179:1756-1767; DOI: 10.1016/j.ajpath.2011.06.002)
Matricellular proteins are a class of extracellular matrix (ECM)-related molecules defined by their ability to modulate cell matrix interactions through binding cell surface receptors such as integrins, as well as extracellular growth factors and collagens. Beside their role in constant ECM remodeling, matricellular proteins are key regulators of matrix accumulation, cell-matrix interaction, and fibrosis. ${ }^{1}$ Thrombospondins (TSPs, protein symbols: THBSs), osteopontin, secreted protein acidic rich in cysteine (SPARC), and members of the CCN family [eg, connective tissue growth factors (CTGF)] are prominent representatives of this group of molecules. ${ }^{2}$ These proteins are highly expressed during development and in very early postnatal tissue. In contrast, expression in healthy adult tissues is usually very low. ${ }^{2}$ Areas where matricellular proteins are under intense investigation range from wound healing and fibrosis to inflammation and tumor progression. ${ }^{3-5}$ In the kidney, osteopontin, thrombospondins, and SPARC are matricellular proteins reported in the pathogenesis of chronic glomerulopathies and tubulointerstitial alteration. ${ }^{6-9}$ As mediators of fibrosis, matricellular proteins represent interesting therapeutic targets to prevent interstitial fibrosis, and by this, development of renal failure. ${ }^{10}$

In a recent study, we generated a comprehensive data set of genes constitutively expressed in the healthy human glomerulus, the renal glomerular gene expression data set (REGGED). ${ }^{11}$ Periostin (POSTN), a matricellular protein previously not studied in the glomerulus, was among these glomerular transcripts predominantly and constitutively expressed in healthy glomeruli. ${ }^{11}$ Because periostin was reported to be mainly expressed in dis-

Supported by grants from the Else Kröner-Fresenius Foundation (A62/04 to C.D.C.), the Swiss National Science Foundation (32-122439/1 to C.D.C. and 32003B_129710 to S.S.), the Novartis Foundation (09B26 to S.S.), the University of Zurich (Forschungskredit, to S.S.), and Applied System Biology Core, O'Brien Renal Center, University of Michigan (P30 DK081943-01 to M.K. and F.E.)

Accepted for publication June 22, 2011.

Supplemental material for this manuscript can be found at $h$ ttp://ajp. amjpathol.org or at doi: 10.1016/j.ajpath.2011.06.002.

Address reprint requests to Clemens D. Cohen, M.D., Institute of Physiology and Division of Nephrology, Winterthurerstrasse 190, CH-8057 Zurich, Switzerland. E-mail: clemens.cohen@access.uzh.ch. 
Table 1. Clinical Characteristics of the Patients Whose Biopsies Were Used for Microarray Analyses

\begin{tabular}{cccccccc}
\hline $\begin{array}{c}\text { Patient } \\
\text { cohort }\end{array}$ & Number & Sex (F/M) & Age (years) & $\begin{array}{c}\text { eGFR } \\
\left(\mathrm{mL} / \mathrm{min} / 1.73 \mathrm{~m}^{2}\right)\end{array}$ & $\begin{array}{c}\text { Creatinine } \\
(\mathrm{mg} / \mathrm{dL})\end{array}$ & $\begin{array}{c}\text { Proteinuria } \\
(\mathrm{g} / \text { day })\end{array}$ & $\begin{array}{c}\text { Hypertension } \\
(\text { yes/no })\end{array}$ \\
\hline MGN Hyb A & 21 & $9 / 12$ & $53.7 \pm 18.0$ & $84.6 \pm 40.1$ & $1.0 \pm 0.4$ & $4.5 \pm 3.1$ & $14 / 7$ \\
MCD Hyb B & 5 & $3 / 2$ & $36.7 \pm 13.5$ & $111.3 \pm 54.9$ & $1.0 \pm 0.8$ & $8.3 \pm 7.0$ & $3 / 2$ \\
FSGS Hyb A & 13 & $5 / 8$ & $47.6 \pm 16.8$ & $63.4 \pm 39.2$ & $1.6 \pm 1.1$ & $4.8 \pm 2.8$ & $9 / 4$ \\
FSGS Hyb B* & 10 & $7 / 3$ & $43.3 \pm 12.7$ & $81.1 \pm 35.1$ & $1.1 \pm 0.6$ & $3.5 \pm 2.2$ & $8 / 2$ \\
LD Hyb A & 14 & $5 / 9$ & $53.2 \pm 11.3$ & $>90$ & $\leq 1.0$ & $<0.2$ & $0 / 14$ \\
LD Hyb B & 18 & $9 / 9$ & $46.8 \pm 12.6$ & $>90$ & $\leq 1.0$ & $<0.2$ & $0 / 18$ \\
\hline
\end{tabular}

*Non-identical glomerular samples from four FSGS patients were hybridized on each array.

eGFR, estimated glomerular filtration rate according to the MDRD (Modification of Diet in Renal Disease) formula; F/M, female/male; FSGS, focalsegmental glomerulosclerosis; Hyb A and B, hybridization on (A) Affymetrix HG-U133A or (B) HG-U133 Plus 2.0, respectively; LD, living donors; MCD, minimal change disease; MGN, membranous glomerulopathy.

eased or fibrotic tissue, we were interested in its expression in diseased glomeruli. We performed a comprehensive screen regarding the expression of matricellular genes in glomeruli from patients with progressive and nonprogressive glomerulopathies. Periostin, although found in REGGED to be constitutively expressed in this compartment of the kidney, showed the highest induction in human glomerular diseases of all of the matricellular proteins. Hence, we followed this finding further and localized periostin protein in renal biopsies and studied the expression of periostin in glomerular cells in vitro.

\section{Materials and Methods}

\section{Renal Biopsies for mRNA Analysis}

Human renal biopsy specimens were collected in an international multicenter study, the European Renal cDNA Bank-Kröner-Fresenius biopsy bank (ERCB-KFB, see Acknowledgments for participating centers). ${ }^{12}$ Biopsies that were all clinically indicated for proteinuria or renal failure were obtained from patients after informed consent and with approval of the local ethics committees. In two independent hybridization experiments, Affymetrix HG-U133A and HG-U133 Plus 2.0 microarrays (Affymetrix, Santa Clara, CA), respectively, were hybridized with glomerular cDNA procured from a total of 77 patients with proteinuric glomerulopathies such as focal-segmental glomerulosclerosis (FSGS, $n=19$ ), membranous ne- phropathy (MGN, $n=21$ ), and minimal change disease (MCD, $n=5)$, as well as pretransplant biopsies from living renal allograft donors as controls $(n=32)$ (Table 1). Confirmatory real-time RT-PCR analyses were performed on microdissected glomeruli from biopsy specimens from additional patients with FSGS $(n=16)$, MGN $(n=14)$, MCD $(n=8)$, proliferative lupus nephritis ISN/RPS III-IV (LN, $n=20)$, and IgA nephropathy (IGAN, $n=14$ ) or on tubulointerstitial specimens from patients with FSGS $(n=$ $25)$ or MGN $(n=28)$ (Table 2). Pretransplant kidney biopsies from living renal allograft donors $(n=6)$ served as controls. Clinical and histological characteristics of the patients and biopsies are summarized in Tables 1 and 2 .

\section{RNA Isolation, Preparation, and Microarray Experiments}

Following renal biopsy, the tissue was transferred to RNase inhibitor and microdissected into glomerular and tubular specimens. ${ }^{12}$ Total RNA was isolated from microdissected glomeruli, reverse transcribed, and linearly amplified according to a protocol previously reported. ${ }^{13}$ Fragmentation, hybridization, staining, and imaging were performed according to the Affymetrix Expression Analysis Technical Manual (Affymetrix). Microarray analysis was performed using a sequence-specific analysis approach, Chiplnspector (Genomatix, Munich, Germany). Here, all probes on the array are individually matched against the genome and all known transcripts thereof.

Table 2. Clinical Data of the Study Population for the Real-Time RT-PCR Studies

\begin{tabular}{lccccc}
\hline \multicolumn{1}{c}{ Diagnosis } & Sex $(\mathrm{F} / \mathrm{M})$ & Age (years) & Creatinine $(\mathrm{mg} / \mathrm{dL})$ & eGFR $(\mathrm{mL} / \mathrm{min})$ & Proteinuria $(\mathrm{g} / \mathrm{day})$ \\
\hline Glomerular specimens & & & & & \\
FSGS & $9 / 7$ & $42.3 \pm 15.8$ & $1.1 \pm 0.6$ & $83.5 \pm 32.2$ & $4.4 \pm 3.4$ \\
MCD & $4 / 4$ & $33.0 \pm 13.7$ & $1.0 \pm 0.6$ & $99.7 \pm 43.1$ & $5.6 \pm 4.7$ \\
MGN & $7 / 7$ & $49.9 \pm 17.9$ & $1.0 \pm 0.4$ & $88.6 \pm 39.9$ & $4.2 \pm 3.3$ \\
LN & $18 / 2$ & $34.2 \pm 11.4$ & $1.3 \pm 0.6$ & $63.1 \pm 24.8$ & $3.1 \pm 3.6$ \\
IGAN & $4 / 10$ & $33.4 \pm 11.5$ & $1.2 \pm 1.0$ & $87.2 \pm 32.5$ & $2.0 \pm 2.7$ \\
LD & $3 / 2$ & $49.8 \pm 11.6$ & $<1.0$ & $>60$ & $<0.2$ \\
Tubulointerstitial specimens & $10 / 15$ & $48.8 \pm 18.1$ & $1.8 \pm 1.1$ & $59.8 \pm 39.2$ & $5.2 \pm 4.9$ \\
$\quad$ FSGS & $14 / 14$ & $60.6 \pm 17.0$ & $1.9 \pm 1.6$ & $55.4 \pm 34.7$ & $6.8 \pm 4.9$ \\
MGN & &
\end{tabular}

For one LD patient age and sex were not available, two FSGS and one MGN patient proteinuria at time of biopsy was not reported.

eGFR, estimated glomerular filtration rate according to the MDRD (Modification of Diet in Renal Disease) formula; F/M, female/male; FSGS, focalsegmental glomerulosclerosis; IGAN, IgA nephropathy; LD, living doors; LN, proliferative lupus nephritis ISN/RPS III/IV; MCD, minimal change disease; MGN, membranous glomerulopathy. 
Only probes that match to one transcript are retained for further analysis. The input data for the significance analysis of microarrays were single probe values, and the resulting probes showing significantly changed signals are then used to identify the corresponding transcripts described. ${ }^{14}$ Parallel analysis using robust multichip average and significance analysis of microarrays gave comparable results. ${ }^{15}$

\section{Quantitative Real-Time RT-PCR}

To confirm the microarray results, we performed real-time RT-PCR studies on biopsy samples from an independent cohort of patients (Table 2). Reverse transcription and real-time RT-PCR were performed as reported previously. ${ }^{12}$ Predeveloped TaqMan reagents were used for human POSTN mRNA and the housekeeper genes GAPDH and 18SrRNA (Applied Biosystems, Darmstadt, Germany). The mRNA expression was analyzed by standard curve quantification. For in vitro studies, reverse transcription was performed as described above. The same predeveloped TaqMan reagents were used. The expression of candidate genes in samples from in vitro studies was analyzed by the delta delta Ct method. ${ }^{12}$

\section{Immunohistochemistry}

Immunohistochemistry was performed as previously described. ${ }^{16}$ In brief, dewaxed and rehydrated tissue sections were incubated in 3\% hydrogen peroxide to block endogenous peroxidases. The Avidin/Biotin blocking kit was used to block endogenous biotin (Vector Laboratories, Burlingame, CA). Antigen retrieval was performed in a microwave oven in hydrochloric acid solution with a pH of $0.9 .{ }^{17}$ The primary antibody was applied for 1 hour, and incubation with the biotinylated secondary antibody for 30 minutes was followed by the $\mathrm{ABC}$ reagent (Vector Laboratories). 3,3'-Diaminobenzidine (Sigma, Taufkirchen, Germany) with metal enhancement (resulting in a black product) was used as a detection system. As previously reported, polyclonal rabbit anti-human periostin antibody was used (RD181045050; Biovendor, Heidelberg, Germany). ${ }^{18,19}$ Human transplant nephrectomy tissue with advanced interstitial fibrosis was used to establish the staining protocol. A heat-based antigen retrieval resulted in a very reliable staining pattern. Blocking experiments were performed with a recombinant periostin protein (RD172045100; Biovendor), which completely abolished the signal. Immunohistochemistry for periostin was performed on formalin-fixed, paraffin-embedded renal biopsies from patients with FSGS $(n=5)$, MGN $(n=12)$, LN ISN/RPS III, IV, IVN $(n=6)$, IGAN $(n=5)$, and pretransplant biopsies as control $(n=5)$ (Table 3). Replacement of the primary antibody by diluent served as an additional negative control. The slides stained for periostin by immunohistochemistry were scanned using the MIRAX Midi Digital Slide Scanner (Carl Zeiss Microlmaging, Jena, Germany). The periostinpositive area was quantified on each slide using the HistoQuant software package of the MIRAX Viewer (Release 1.12; Carl Zeiss Microlmaging). The analysis was done separately for glomeruli and tubulointerstitium. The positive area was expressed as percentage of the evaluated area.

Consecutive sections of human transplant nephrectomy tissue were stained for periostin and cell-type markers such as $\alpha$-smooth muscle actin ( $\alpha$-SMA, M0851; DAKO, Glostrup, Denmark), Wilms tumor 1 (WT1, sc-192; Santa Cruz Biotechnology, Santa Cruz, CA), and platelet endothelial cell adhesion molecule 1 (PECAM1/CD31, M0823; DAKO).

\section{Immunofluorescence}

Multicolor immunofluorescence was performed for periostin, $\alpha$-SMA, and PECAM1 on kidney transplant nephrectomy tissue. The monoclonal antibodies for $\alpha$-SMA and PECAM1 (M0851 and M0823; DAKO) were visualized with a Cy3labeled secondary antibody (Invitrogen, Basel, Switzerland). Periostin (RD181045050; Biovendor) was visualized by a biotinylated secondary antibody and labeled with fluorescein isothiocyanate bound to streptavidin (Vector Laboratories). Negative controls consisted of isotype immunoglobulins or non-immune serum (not illustrated).

\section{Cell Culture}

Human mesangial cells $(\mathrm{HMC})^{20}$ were grown in Dulbecco's modified Eagle's medium (DMEM)+GlutaMAX-I (Gibco, Invitrogen) containing 10\% fetal bovine serum (FBS) and 1\% penicillin/streptomycin (P/S). Murine mesangial cells $(\mathrm{MMC})^{21}$ were grown in DMEM (Gibco, Invitrogen) containing 5\% FBS, $1 \% \mathrm{P} / \mathrm{S}, 2 \mathrm{mmol} / \mathrm{L}$ L-glutamine, and $10 \mathrm{mmol} / \mathrm{L}$ HEPES (Gibco, Invitrogen). Cells were incubated at $37^{\circ} \mathrm{C}$ in a humidified atmosphere of $5 \%$ $\mathrm{CO}_{2}$ in air. All experiments, but for the TGF- $\beta 1$ stimulation, were performed in both cell lines with comparable results. HMC were not used for TGF- $\beta 1$ stimulation because the current passages of the cell line showed no appropriate response to external TGF- $\beta 1$ in control experiments (eg, fibronectin expression).

\section{Western Blot Analysis}

Cultured $\mathrm{HMC}$ and $\mathrm{MMC}$ were harvested with radioimmunoprecipitation assay buffer composed of $150 \mathrm{mmol} / \mathrm{L}$ $\mathrm{NaCl}, 1 \%(\mathrm{v} / \mathrm{v})$ Nonidet P40, 0.5\% (v/v) sodium deoxycholate, $0.1 \%(\mathrm{v} / \mathrm{v}) \mathrm{SDS}$, and $50 \mathrm{mmol} / \mathrm{L}$ Tris ( $\mathrm{pH}$ 8). The protein concentrations of the supernatants were determined by the Bradford method (Bio-Rad Laboratories, Hercules, CA). Extracted proteins were boiled in loading buffer for 5 minutes, resolved by 10\% SDS-polyacrylamide gel electrophoresis under reducing conditions, and transferred to an Immobilon-P membrane (Millipore, Eschborn, Germany). Membranes were blocked for 1 hour with Tris-buffered saline/3\% fat-free skim milk and then incubated with the polyclonal rabbit antibody raised against human periostin (1:5000; Biovendor) overnight at $4^{\circ} \mathrm{C}$ and rinsed with Tris-buffered saline containing $0.1 \%$ Tween 20. For detection, a horseradish peroxidaselinked anti-rabbit IgG antibody (1:10,000, 1 hour at room temperature; DAKO) and enhanced chemiluminescence 
Table 3. Clinical Data of the Patients Selected for Immunohistochemistry and Semiquantitative Data for the Periostin Staining

\begin{tabular}{|c|c|c|c|c|c|c|c|}
\hline $\begin{array}{l}\text { Diagnosis } \\
\text { case no. }\end{array}$ & Sex & Age (years) & $\begin{array}{l}\text { Creatinine } \\
(\mathrm{mg} / \mathrm{dL})\end{array}$ & $\begin{array}{c}\text { Proteinuria } \\
\text { (g/day) }\end{array}$ & eGFR (mL/min) & $\begin{array}{c}\text { Positive area } \\
\text { interstitium }\end{array}$ & $\begin{array}{c}\text { Positve area } \\
\text { glomerulus }\end{array}$ \\
\hline FSGS-H1 & M & 36 & 9.5 & 0.1 & 6.7 & $28.9 \%$ & $10.7 \%$ \\
\hline FSGS-H2 & M & 55 & 3.0 & 2.0 & 23.6 & $8.8 \%$ & $5.0 \%$ \\
\hline FSGS-H3 & $\mathrm{M}$ & 65 & 1.6 & 3.5 & 45.0 & $1.7 \%$ & $12.7 \%$ \\
\hline FSGS-H4 & M & 29 & 1.3 & 0.6 & 70.7 & $2.7 \%$ & $7.2 \%$ \\
\hline FSGS-H5 & M & 42 & 0.6 & 1.5 & 144.5 & $0.8 \%$ & $3.2 \%$ \\
\hline IGAN-H1 & $\mathrm{F}$ & 45 & 3.2 & 1.7 & 16.8 & $24.9 \%$ & $24.3 \%$ \\
\hline IGAN-H2 & M & 26 & 1.5 & 0.5 & 58.4 & $0.4 \%$ & $14.9 \%$ \\
\hline IGAN-H3 & M & 33 & 1.1 & 0.4 & 78.4 & $0.2 \%$ & $2.0 \%$ \\
\hline IGAN-H4 & M & 40 & 1.0 & 0.4 & 87.3 & $0.2 \%$ & $7.6 \%$ \\
\hline IGAN-H5 & M & 16 & 0.9 & 3.6 & 120.6 & $1.5 \%$ & $6.8 \%$ \\
\hline LN-H1 & $\mathrm{F}$ & 30 & 2.2 & 12.9 & 28.4 & $14.9 \%$ & $20.3 \%$ \\
\hline LN-H2 & $\mathrm{F}$ & 73 & 1.1 & 4.5 & 51.3 & $2.2 \%$ & $9.1 \%$ \\
\hline LN-H3 & $\mathrm{F}$ & 22 & 0.8 & 1.0 & 94.9 & $2.0 \%$ & $2.1 \%$ \\
\hline LN-H4 & $\mathrm{F}$ & 23 & 0.8 & 6.6 & 98.9 & $0.2 \%$ & $9.5 \%$ \\
\hline LN-H5 & $\mathrm{F}$ & 21 & 0.7 & 2.6 & 118.6 & $6.5 \%$ & $16.7 \%$ \\
\hline LN-H6 & M & 43 & 0.7 & 9.2 & 138.2 & $0.6 \%$ & $8.8 \%$ \\
\hline MGN-H1 & M & 38 & 5.8 & 3.2 & 11.6 & $14.0 \%$ & $23.5 \%$ \\
\hline MGN-H2 & $\mathrm{F}$ & 80 & 1.2 & 13.0 & 46.0 & $7.0 \%$ & $2.7 \%$ \\
\hline MGN-H3 & $\mathrm{F}$ & 59 & 1.2 & 7.8 & 50.0 & $5.3 \%$ & $9.2 \%$ \\
\hline MGN-H4 & $\mathrm{F}$ & 66 & 1.1 & 2.5 & 53.0 & $5.5 \%$ & $12.4 \%$ \\
\hline MGN-H5 & M & 67 & 1.2 & 3.0 & 67.2 & $2.7 \%$ & $9.8 \%$ \\
\hline MGN-H6 & M & 68 & 1.0 & 3.0 & 77.4 & $1.6 \%$ & $7.8 \%$ \\
\hline MGN-H7 & $\mathrm{F}$ & 65 & 0.7 & 5.4 & 94.3 & $0.7 \%$ & $4.1 \%$ \\
\hline MGN-H8 & $M$ & 33 & 1.0 & 11.4 & 97.0 & $5.6 \%$ & $7.1 \%$ \\
\hline MGN-H9 & M & 66 & 0.8 & 17.5 & 102.3 & $1.9 \%$ & $9.3 \%$ \\
\hline MGN-H10 & $\mathrm{M}$ & 50 & 0.8 & 5.0 & 111.9 & $1.6 \%$ & $3.7 \%$ \\
\hline MGN-H11 & $\mathrm{F}$ & 30 & 0.6 & 4.4 & 114.8 & $1.4 \%$ & $12.8 \%$ \\
\hline MGN-H12 & $\mathrm{F}$ & 47 & 0.5 & 4.0 & 145.1 & $0.2 \%$ & $6.9 \%$ \\
\hline Pre-Tx-H1 & M & 21 & NA & NA & NA & $0.0 \%$ & $1.3 \%$ \\
\hline Pre-Tx-H2 & M & 52 & NA & NA & NA & $6.7 \%$ & $13.9 \%$ \\
\hline Pre-Tx-H3 & $\mathrm{F}$ & 42 & NA & NA & NA & $0.1 \%$ & $1.4 \%$ \\
\hline Pre-Tx-H4 & $\mathrm{F}$ & 64 & NA & NA & NA & $0.0 \%$ & $2.2 \%$ \\
\hline Pre-Tx-H5 & $M$ & 54 & NA & NA & NA & $0.3 \%$ & $6.4 \%$ \\
\hline
\end{tabular}

eGFR, estimated glomerular filtration rate according to the MDRD (Modification of Diet in Renal Disease) formula; F/M, female/male; FSGS, focalsegmental glomerulosclerosis; IGAN, IgA nephropathy; LN, proliferative lupus nephritis ISN/RPS III/IV; MCD, minimal change disease; MGN, membranous glomerulopathy; Pre-Tx, pretransplant biopsy taken before implantation of the allograft.

substrate (PerkinElmer Life and Analytical Sciences, Waltham, MA) were used. $\beta$-Actin (Sigma) was used as loading control in Western blot analyses.

\section{TGF- $\beta 1$ Stimulation}

MMC were starved in medium containing 0.5\% FBS 24 hours before incubation with $2.5 \mathrm{ng} / \mathrm{mL}$ of human TGF- $\beta 1$ (R+D Systems, Abingdon, UK) for 2, 4, and 6 hours, respectively. This time-dependent analysis showed highest induction at 4 hours, hence dose-dependence was tested at 4 hours with 0.1 to $10 \mathrm{ng} / \mathrm{mL}$ TGF- $\beta 1$. Total cellular RNA was extracted using Qiagen RNeasy kit (Qiagen, Hombrechtikon, Switzerland). The mRNA expression was analyzed by real-time RT-PCR.

\section{Proliferation Assay and Caspase-3 Staining}

HMC and MMC were plated at a concentration of 5000 cells per well (60\% confluency) on a 96-well plate. The cells were grown initially in DMEM+GlutaMAX-I medium supplemented with $10 \%$ FBS and $1 \% \mathrm{P} / \mathrm{S}$ or DMEM containing 5\% FBS, $1 \% \mathrm{P} / \mathrm{S}, 2 \mathrm{mmol} / \mathrm{L}$ L-glutamine, and $10 \mathrm{mmol} / \mathrm{L}$ HEPES, respectively. Cells were starved in medium containing $0.5 \%$ FBS 24 hours before incubation with 1 to $100 \mathrm{ng} / \mathrm{mL}$ recombinant periostin protein for 48 hours. Cell proliferation was measured with the Promega Cell Titer 96 MTS assay method (Promega, Madison, WI).

To study the effect of periostin on apoptosis of mesangial cells, HMC were stained for activated caspase-3. $\mathrm{HMC}$ seeded on glass coverslips were starved in medium containing $0.5 \%$ FBS 24 hours before incubation with $10 \mathrm{ng} / \mathrm{mL}$ recombinant periostin protein or vehicle for 48 hours. Coverslips were fixed in $4 \%$ paraformaldehyde and incubated with $0.1 \%$ Triton-X 100 in PBS. After blocking with PBS containing 3\% BSA and $0.05 \%$ NP-40 for 1 hour, the primary caspase-3 antibody (Cell Signaling Technology Inc., Beverly, MA) was applied overnight at $4^{\circ} \mathrm{C}$ followed by a biotinylated secondary antibody and fluorescein isothiocyanate bound to streptavidin (Vector Laboratories). Quantification of caspase-3-positive and -negative cells was performed by ImageJ (version 1.45e, National Institutes of Health, Bethesda, MD) after mounting with DAPI.

\section{Statistics}

Experimental data are given as mean \pm SD. Where appropriate, statistical analyses were performed using 


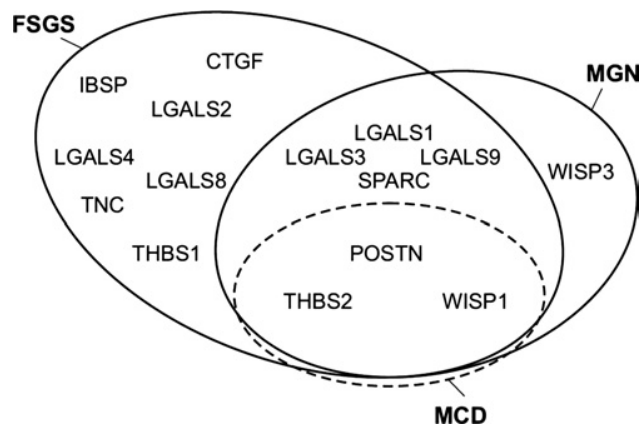

Figure 1. Venn diagram of matricellular proteins induced in proteinuric diseases. Transcript levels of 15 matricellular proteins that were found to be induced in glomeruli from patients with proteinuric diseases are indicated. In both progressive glomerulopathies, FSGS and MGN, more matricellular proteins were induced than in the nonprogressive disease MCD Periostin, although constantly expressed in this renal compartment, showed the highest induction of all matricellular proteins (see Supplemental Table S1 at http://ajp.amjpathol.org). Abbreviations represent the official gene symbols of the matricellular proteins: IBSP, bone sialoprotein; POSTN, periostin; TNC, tenascin-C; WISP1, -3, WNT1 Inducible Signaling Pathway protein-1, -3

Kruskall-Wallis, Mann-Whitney U-tests, and Pearson's correlation using SPSS 17.0 (SPSS., Chicago, IL), respectively. $P$ values $<0.05$ were considered to indicate statistically significant differences.

\section{Results}

\section{Glomerular Transcriptional Levels of Matricellular Proteins in Proteinuric Diseases}

The steady-state mRNA expression of genes encoding matricellular proteins was first studied by microarrays on microdissected glomeruli from renal biopsies of patients with different proteinuric diseases and controls (FSGS, $n=19$; MGN, $n=21$; MCD, $n=5$; controls, $n=$ 32, Table 1). The expression of bone sialoprotein, CTGF, CYR61, galectins (LGALS) 1-4, 8, and 9, NOV, osteonectin (SPARC), osteopontin, periostin, tenascin-C, THBS-1 and -2, and WNT1 Inducible Signaling Pathway proteins -1 to -3 were studied. The expression of 15 of these 19 known matricellular proteins was transcriptionally induced in glomeruli from patients with proteinuric diseases (Figure 1; see also Supplemental Table S1 at http://ajp.amjpathol.org). Interestingly, the mRNA levels of 12 of these 15 genes were induced in progressive glomerulopathies such as FSGS and MGN, but not in nonprogressive MCD. This would be consistent with a functional role of matricellular proteins in the progression to sclerosis and loss of renal function in acquired nephropathies. The strongest induction was found for periostin, again most prominently in the progressive disease FSGS, less in MGN, and only mild in MCD (FSGS: 2.5-fold compared with living donor samples, MGN: 2.0-fold; MCD: 1.5-fold, all statistically significant compared to controls; see Supplemental Table S1 at $h t t p: / / a j p . a m j p a t h o l . o r g)$.

\section{Localization of Periostin in Well-Preserved Renal Tissue}

This strong induction of periostin mRNA was unexpected because we previously found periostin to be constantly expressed in the human glomerulus, making a high foldchange even more significant compared with genes with lower constitutive expression. ${ }^{11}$ To confirm first that periostin mRNA is indeed overrepresented in healthy glomeruli compared to the tubulointerstitial compartment, we performed quantitative real-time RT-PCR for periostin mRNA on microdissected glomeruli and tubulointerstitium of pretransplant biopsies from living renal allograft donors $(n=13)$. Consistent with our previous microarray report, ${ }^{11}$ periostin demonstrated a 31.1-fold $( \pm 29.8, P<$ 0.001 ) higher expression in microdissected glomeruli as compared to tubulointerstitial specimens. However, a high variance of steady state expression was observed (Figure 2).

To further study the expression and localization of the periostin protein in renal tissue, immunohistochemistry was established on formalin-fixed, paraffin-embedded renal tissue. Immunohistochemistry for periostin was performed in renal tissue of five biopsies from allografts taken before implantation as controls. The tissue in these biopsies was generally well preserved. As predicted by the mRNA expression, periostin was mainly found in glomerular areas, but not in the tubulointerstitium in these controls (Figure 3, A and B). In glomeruli, the staining was rarely localized within the peripheral glomerular tuft, but was prominent close to the vascular pole. Bowman's capsule was regularly periostin-positive. No expression by tubular epithelial cells was observed. Within the normal tubular interstitium, no periostin staining was present in the pretransplant biopsies, despite very focal sites of interstitial fibrosis (Figure 3B). On the contrary, human transplant nephrectomy tissue with advanced interstitial fibrosis, used to establish the staining protocol, also showed, besides a strong positivity in the glomerular vascular pole and tuft, a prominent periostin signal in regions

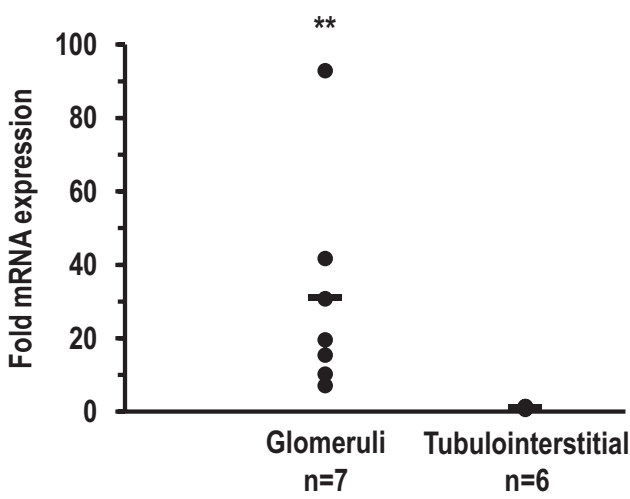

Figure 2. Periostin mRNA is enriched in the glomerular compartment. Expression of periostin mRNA was analyzed by real-time RT-PCR in glomerular and tubulointerstitial samples from pretransplant biopsies. The expression in the glomerular compartment was $>30$-fold higher compared with the tubulointerstitium. ${ }^{* *} P<0.01$; data shown are normalized to GAPDH, and tubulointerstitial expression was set as 1 . 

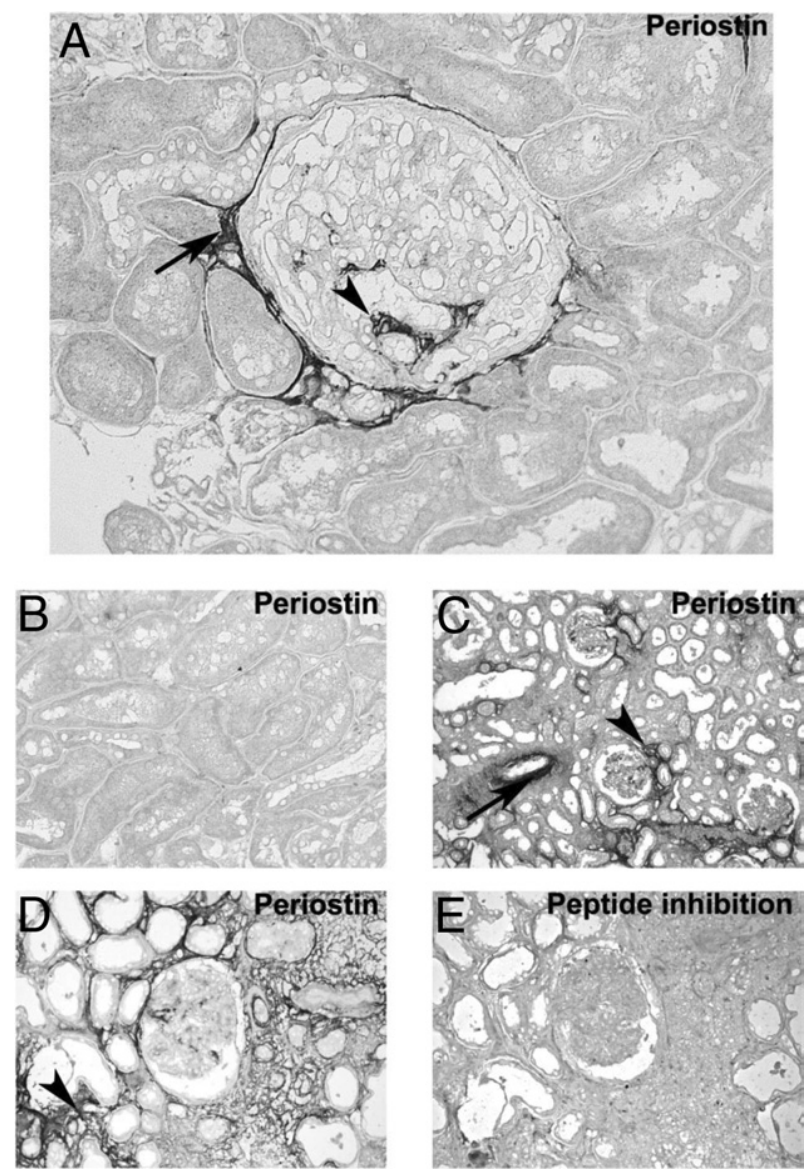

Figure 3. Localization of periostin in human pretransplant biopsies and transplant nephrectomies. Immunohistochemistry was performed with a polyclonal antiserum against periostin $(\mathbf{A}-\mathbf{D})$ or the combination of antiserum and the corresponding peptide (E) on pretransplant biopsies [original magnification, $\times 250$ (A and $\mathbf{B}$ )] and allograft nephrectomies [original magnification: $\times 100(\mathbf{C}) ; \times 250(\mathbf{D}$ and $\mathbf{E})$ ]. A: In well-preserved tissue from pretransplant biopsies, a positivity was rarely found for periostin within the glomerular tuft (arrowhead), but commonly at the vascular pole and along the Bowman's capsule (arrow). B: No periostin staining was detected in the well-preserved tubulointerstitium from pretransplant biopsies. C and D: In transplant nephrectomies due to chronic dysfunction, periostin was strongly positive in regions with interstitial fibrosis (arrowheads) and constitutively expressed in the wall of larger arteries (arrow in C). E: Addition of recombinant periostin completely blocked the specific staining of the primary antibody (consecutive section to $\mathbf{D}$ ).

with interstitial fibrosis in this chronically damaged renal tissue (Figure 3, C and D). Here, periostin was also found in the media of medium-sized arteries (Figure 3C). Specificity of the staining was tested by blocking experiments with recombinant periostin (Figure 3, D and $E)$.

\section{Expression and Localization of Periostin in Different Acquired Glomerulopathies}

The periostin mRNA induction in proteinuric glomerulopathies was validated by real-time RT-PCR. Periostin mRNA expression was studied in microdissected glomeruli from patients with FSGS $(n=16), \operatorname{MGN}(n=14), \operatorname{MCD}(n=8)$, controls $(n=6)$, and two additional progressive proteinuric diseases, LN $(n=20)$ and IGAN $(n=14)$ (Table 2). Corresponding to the microarray data, an induction of periostin was found in progressive glomerulopathies such as LN (12.9 $\pm 24.1, P<0.001)$, FSGS $(2.3 \pm 1.4$, $P<0.05)$, but not in MCD $(2.8 \pm 3.5$, NS). In MGN (1.9 \pm $1.4, N S)$, and IGAN (3.3 $\pm 3.9, N S)$, a trend for induction was seen but missed significance, potentially due to the above-mentioned considerable variance in periostin steady state expression even in healthy glomeruli (Figure 4, A and B).

Furthermore, periostin was localized by immunohistology in renal biopsies from patients with FSGS $(n=5)$, MGN $(n=12)$, proliferative LN ISN/RPS III, IV, IV N $(n=$ $6)$, IGAN $(n=5)$, and controls mentioned above $(n=5)$. The clinical parameters of the patients are summarized in Table 3. In contrast to the occasional glomerular staining in pretransplant biopsies, periostin was prominently and diffusely present in the glomerular tuft from patients with MGN and LN (Figure 5, A-D). This periostin positivity was consistent with a mesangial distribution (Figure 5, A-D). Additionally, the positivity was found in some biopsies in the periphery of the glomerular capillaries (Figure 5C).

The results from a quantitative image analysis of the periostin staining are summarized in Table 3. All patients with LN demonstrated a prominent and diffuse glomerular staining pattern. In one patient with LN and sequential biopsies, the mesangial positivity clearly increased with
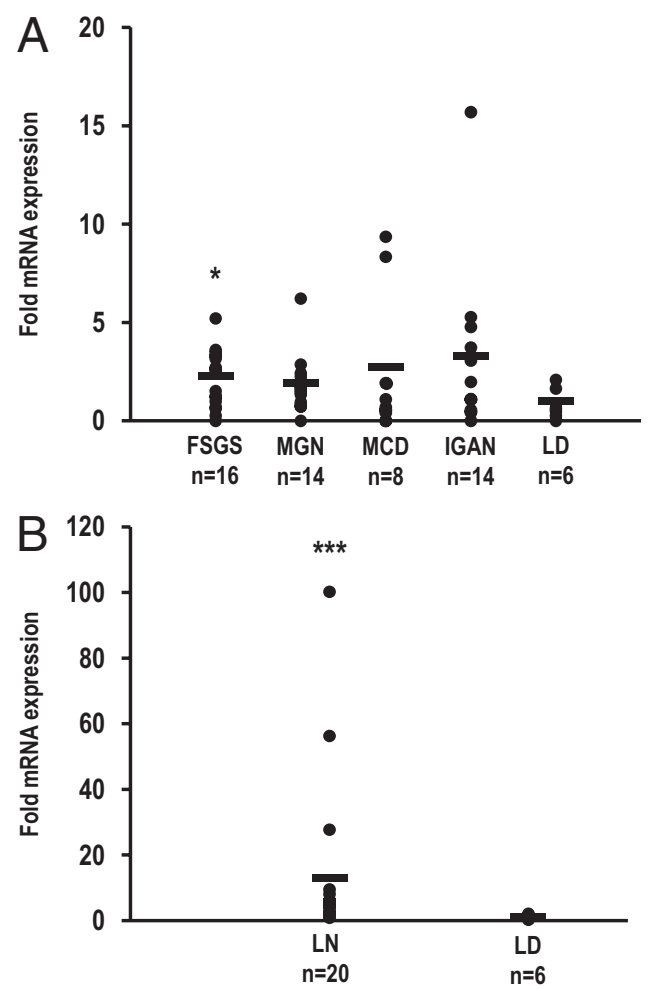

Figure 4. Periostin mRNA expression in different glomerulopathies. Periostin mRNA is induced in progressive glomerulopathies such as FSGS and LN. A: The expression of periostin mRNA is shown as fold-change compared with living donors (LD). FSGS, focal-segmental glomerulosclerosis; IGAN, IgA nephropathy; MCD, minimal change disease; MGN, membranous glomerulopathy. B: Periostin mRNA showed the highest induction in proliferative lupus nephritis compared with LD. ${ }^{*} P<0.05$, ${ }^{*}{ }^{*} *{ }^{*} P<0.001$. Data are shown as fold-change compared to expression in LD (set as 1) and are normalized to GAPDH. 

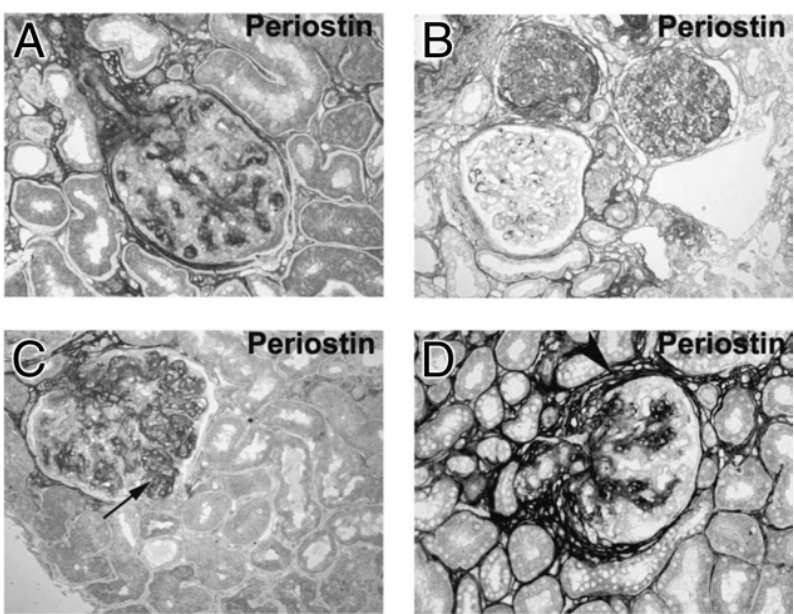

Figure 5. Periostin staining in membranous nephropathy and proliferative lupus nephritis. Immunohistochemistry was performed with a polyclonal antiserum against periostin (A-D) on renal biopsies with membranous nephropathy (A and $\mathbf{B}$ ), lupus nephritis $(\mathbf{C}$ and $\mathbf{D})$, [original magnification, $\times 200$ (A-D)]. A: The typical constitutive staining of the vascular pole is illustrated in combination with a prominent staining of the glomerular tuft with a predominant mesangial pattern in a biopsy with membranous nephropathy, B: Three glomeruli with different grades of glomerular staining are illustrated ranging from focal staining (left glomerulus), to global staining in a completely sclerosed glomerulus (in the middle). $\mathbf{C}$ and $\mathbf{D}$ : In two patients with LN ISN/RPS IV and comparably high proteinuria ( 7 to $8 \mathrm{~g} /$ day), the glomerular periostin staining was similar. However, the tubulointerstitia periostin staining was mild in the patient with preserved eGFR $(>60 \mathrm{~mL} / \mathrm{min}$; C, arrow: glomerular periphery) and prominent in the patient with impaired renal function and interstitial fibrosis (eGFR $<30 \mathrm{~mL} / \mathrm{min}$; $\mathbf{D}$, arrowhead).

duration of kidney disease and loss of renal function. In FSGS, the periostin staining was found accentuated in areas of sclerosis, but mesangial positivity was found to be similar to that in healthy glomeruli. In IGAN, a disease with no significant mRNA induction found by real-time RT-PCR, the staining was also not significantly different to control tissue.

\section{Periostin Expression in the Tubulointerstitium and in Biopsies with Renal Failure}

As described above, the staining of transplant nephrectomies was strongly positive for periostin in the tubular interstitium at sites of fibrosis and interstitial inflammation (Figure 3, C and D). This was also seen in renal biopsies from patients with glomerulopathies and reduced renal function (Figure 5, B and D). In contrast to the periostinnegative tubulointerstitium in healthy renal tissue, the interstitium became increasingly periostin-positive with loss of renal function independent of the type of glomerulopathy. Periostin-positive staining was found most prominently in areas with interstitial matrix accumulation and tubular atrophy. For example, stainings for lupus nephritis patients with comparable amounts of proteinuria but different estimated GFR (eGFR) are shown (Figure 5, C and D). Quantitative image analysis was applied and, in biopsies from patients with an eGFR $<30 \mathrm{~mL} / \mathrm{min}$, showed a significantly more prominent tubulointerstitial periostin staining than in biopsies with well-preserved renal function (Figure 6 A). This was also indicated by a significant negative correlation between the periostin-positive areas in the interstitium of biopsies from all patients with different nephropathies and the eGFR $(r=-0.695, P<$ 0.001). Similarly, quantitative analysis of the glomerular signal showed the highest scores for glomerular periostin in biopsies from patients with an eGFR $<30 \mathrm{~mL} / \mathrm{min}$, and again, a significant negative correlation was found for the periostin-positive glomerular area and eGFR of the patient $(r=-0.472, P=0.01$, Figure 6B). Staining scores of the tubulointerstitial and glomerular areas in each biopsy showed a statistically significant positive correlation $(r=$ 0.597, $P<0.001)$

To further substantiate the negative correlation of periostin expression and eGFR, the more quantitative
A

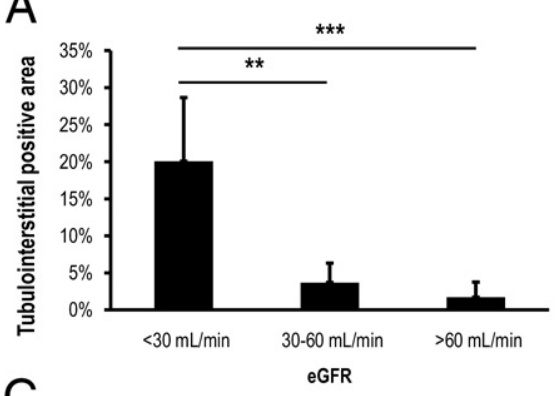

C

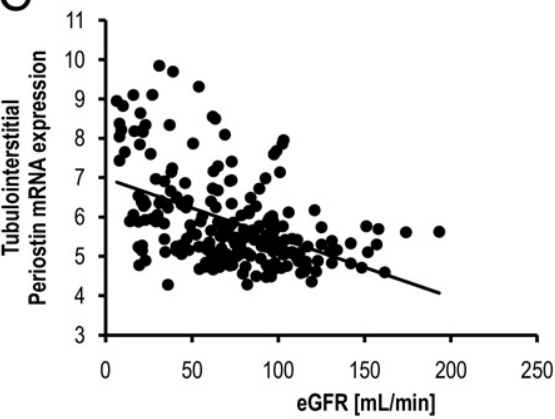

B

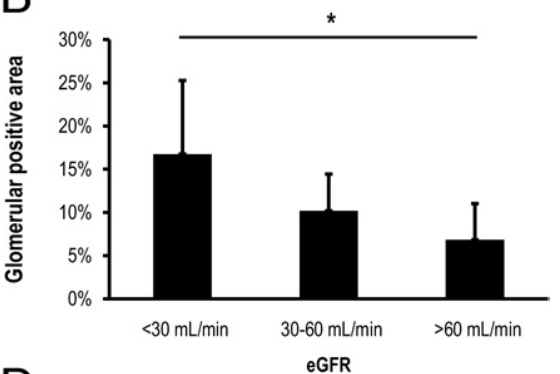

D

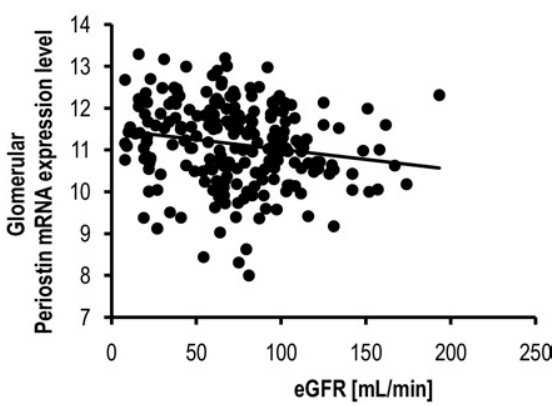

Figure 6. Periostin correlates negatively with renal function. A and B: Digital image analysis was performed to quantify the periostin-positive area. A: Periostin staining was most prominent in the interstitium of biopsies from patients with an eGFR $<30 \mathrm{~mL} / \mathrm{min}$ (**: $P<0.01$ vs. eGFR $30-60$ $\mathrm{mL} / \mathrm{min}$ and ${ }^{\text {**** }} P<0.001 \mathrm{vs}$. eGFR $>60 \mathrm{~mL} / \mathrm{min}$ respectively). B: The same enhanced periostin positivity can be seen in the glomerular compartment of biopsies with reduced GFR $\left({ }^{*} P<0.05\right.$ eGFR $<30 \mathrm{~mL} / \mathrm{min}$ vs eGFR $>60 \mathrm{~mL} / \mathrm{min}$ ). C and D: In a comprehensive transcriptomic screen on biopsies from patient with different nephropathies $(n=221)$, periostin mRNA expression was correlated with eGFR of the patients. Intrarenal periostin mRNA levels showed a significant, negative correlation with eGFR in both tubulointerstitium (C) and glomeruli (D) (tubulointerstitium: $r=-0.47, P=6.9^{-14}$, glomeruli: $r=$ $\left.-0.18, P=8.1^{-03}\right)$ 


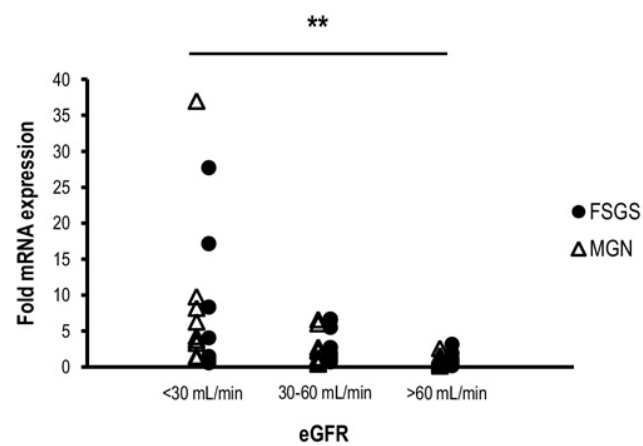

Figure 7. Periostin mRNA expression in tubulointerstitium. Periostin mRNA levels in the tubulointerstitium were quantified by real-time RT-PCR in biopsies from patients with FSGS $(n=25)$ and MGN $(n=28)$, with a wide range of eGFR. Highest periostin mRNA levels were found in biopsies from patients with eGFR $<30 \mathrm{~mL} / \mathrm{min}\left({ }^{* *} P<0.01\right.$, data are shown as fold-change compared to the eGFR $>60 \mathrm{~mL} / \mathrm{min}$ group).

data from a comprehensive transcriptomic screen were analyzed. ${ }^{22}$ Periostin mRNA expression showed a significant, negative correlation with renal function in both compartments (tubulointerstitium: $r=-0.47, P=6.9^{-14}$, glomeruli: $r=-0.18, P=8.1^{-03} ; n=221$ ) (Figure $6, \mathrm{C}$ and D). No statistically significant correlations were found for the intensity score or mRNA expression with proteinuria or age of the patients, respectively. We also tested the glomerular expression of other matricellular proteins for correlation with renal function. For 6 of 19 genes (including POSTN), glomerular expression levels correlated negatively with eGFR (see Supplemental Table S1 at http://ajp.amjpathol.org). No correlation with reported levels of proteinuria was observed. To substantiate the tubulointerstitial data from the transcriptomic screen, real-time RT-PCR for periostin mRNA was performed. On microdissected tubulointerstitium from patients with FSGS and MGN with a wide range of eGFR ( $n=25$ and 28 , respectively; Table 2), again a significant negative correlation of periostin expression levels with eGFR was seen $(r=-0.374, P<0.01$, Figure 7$)$.

\section{Mesangial Cells Produce Periostin and Respond to It with Proliferation and Reduced Rate of Apoptosis}

Periostin is known to be produced in most organs by fibroblasts or fibroblast-like cells. ${ }^{23}$ To determine whether this is also true in the kidney, we performed co-immunofluorescence for smooth muscle actin ( $\alpha$-SMA) and periostin in transplant nephrectomies. Periostin localized to the extracellular matrix in close vicinity to $\alpha$-SMApositive cells but without overlap of both signals (Figure $8, A-C)$. Such proximity of both signals has been illustrated previously in other organs (see Discussion and Kikuchi et $\mathrm{al}^{24}$ ). Because mesangial cells are the glomerular cells expressing $\alpha$-SMA during glomerular injury, ${ }^{25}$ the staining would indicate that mesangial cells are the source of periostin in the glomerulus. By co-immunofluorescence with PECAM1, an endothelial marker, no overlap or proximity with periostin was seen. Staining of consecutive sections for WT1 (a podocyte marker), PECAM1, and periostin showed also no overlap or common staining pattern. Again, however, a clear proximity of periostin and $\alpha$-SMA was observed (Figure 8, D-J). These stainings suggest mesangial cells to be the source of glomerular periostin. In the interstitium, a similar proximity of periostin and $\alpha$-SMA was seen, indicating an expression by interstitial myofibroblasts. ${ }^{23}$

The glomerular staining and periostin induction in disease prompted us to study periostin in mesangial cells in vitro. Consistent with the staining pattern, supernatant from both human and murine mesangial cells was found to be positive for periostin by Western blot analysis (Figure 9A). In addition, mesangial cells showed a time- and dose-dependent induction of periostin mRNA when treated with TGF- $\beta 1$, a known stimulator of periostin in other cell types (Figure 9B). We aimed to translate this finding to human data and looked for association of
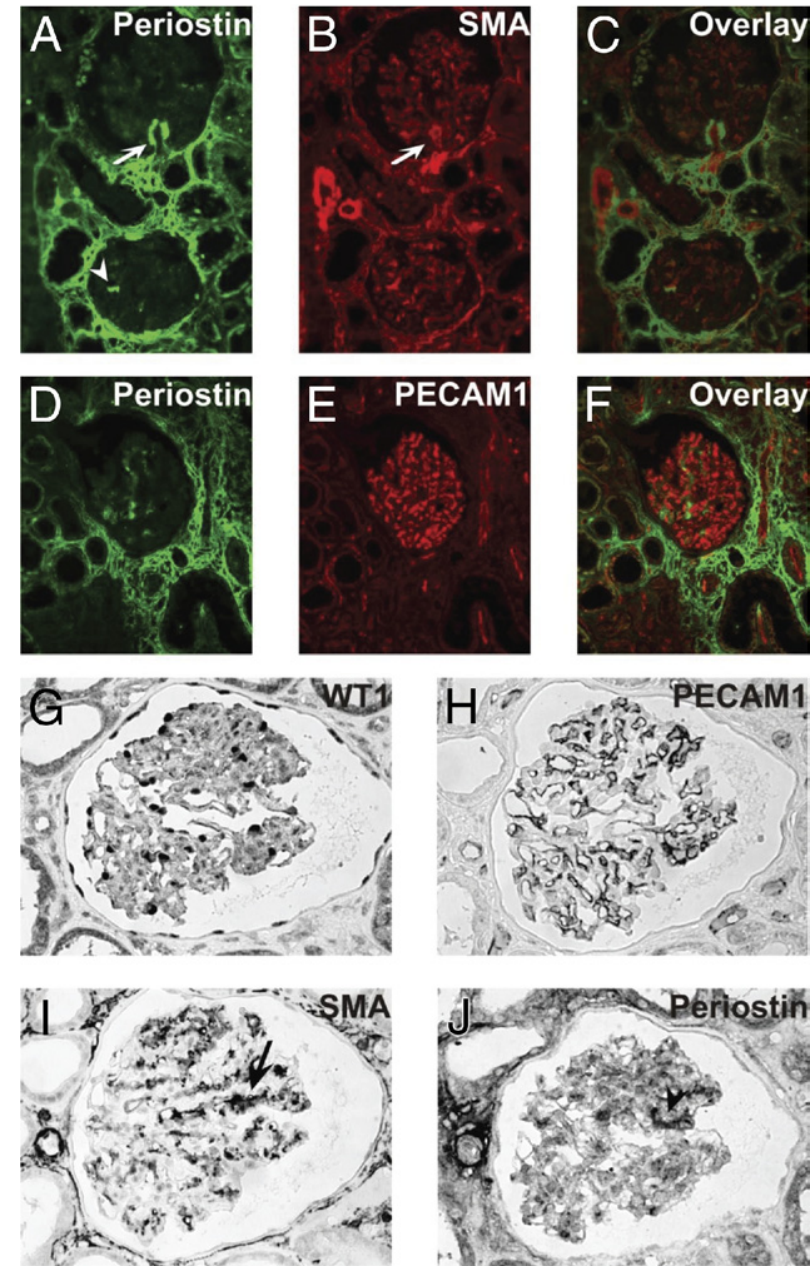

Figure 8. Co-immunofluorescence and consecutive sections for periostin, $\alpha$-SMA, PECAM1, and WT1. A transplant nephrectomy was stained for periostin (A) and $\alpha$-smooth muscle actin ( $\alpha$-SMA) (B). The merge (C) indicates no overlap of both signals but clear and consistent proximity of both molecules in both glomeruli (arrows) and in the tubulointerstitium. Focal staining in the periphery of glomerular tuft is illustrated by the arrowhead. No such proximity or any overlap was seen by co-immunofluorescence for periostin and PECAM1 (D-F). Consecutive sections of human transplant nephrectomy tissue were also stained for the cell-type markers WT1 (G), PECAM1 (H), $\alpha$-SMA (I), and for periostin (J). Again, a clear proximity of $\alpha$-SMA and periostin were observed, illustrated by arrow and arrowhead, and no overlap or obvious proximity with WT1 or PECAM1. 

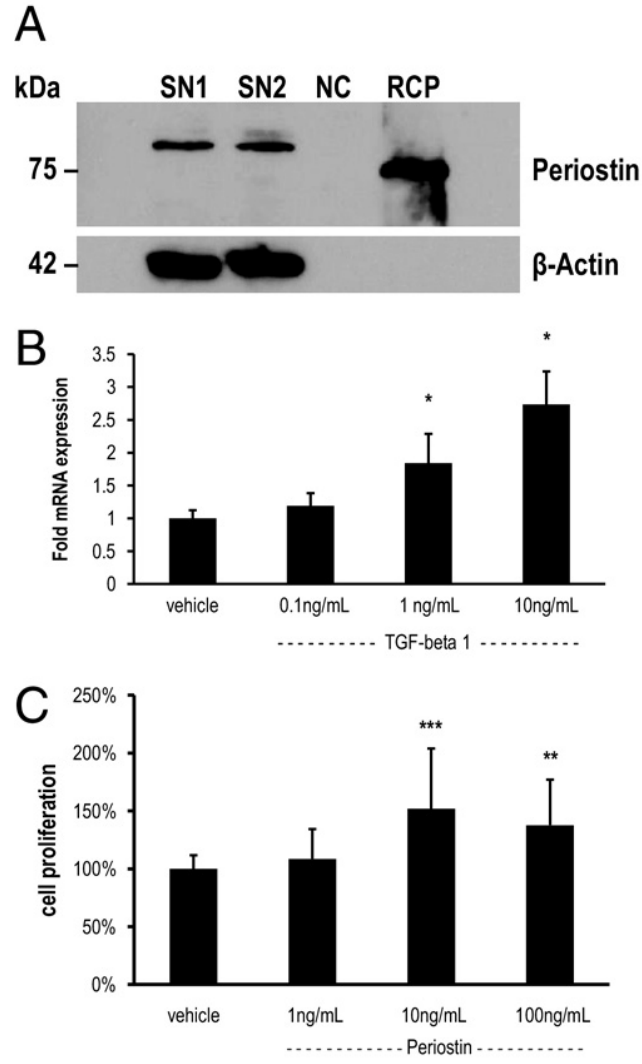

Figure 9. Periostin is produced by mesangial cells in vitro and induces cell proliferation. A: Western blot analysis for periostin showed a single band of the expected size in human and murine mesangial cell supernatants (SN1, $\mathrm{SN} 2$, respectively); a truncated recombinant periostin protein served as positive control (RCP; $75 \mathrm{kDa}$; Biovendor). Water served as negative control (NC). B: Murine mesangial cells were incubated with TGF- $\beta 1$ at the indicated concentrations for 4 hours. This stimulation led to a dose-dependent induction of periostin mRNA ( ${ }^{*} P<0.05$ vs vehicle control; $n=4$ each). C: Cell proliferation was tested on mesangial cells incubated in the absence and presence of varying concentrations of periostin. Highest proliferative effect was found for $10 \mathrm{ng} / \mathrm{mL}$ periostin. The results are shown from human mesangial cells and are summarized from four independent experiments with three to eight stimulations each. ${ }^{* *} P<0.01,{ }^{* * * *} P<0.001$ versus vehicle control. Murine mesangial cells gave comparable results with highest induction at $10 \mathrm{ng} / \mathrm{mL}$ periostin.

TGF- $\beta 1$ and periostin mRNA levels in human glomeruli. In the comprehensive transcriptomic data set from patients with different nephropathies, TGF- $\beta 1$ mRNA levels correlated positively with periostin mRNA expression (glomeruli: $r=0.204, P<0.01$ and tubulointerstitium: $r=0.168$, $P<0.001 ; n=221$ ). To determine whether periostin accelerates mesangial cell proliferation as it does in other cell types, ${ }^{24,26}$ we incubated human mesangial cells for 48 hours with recombinant periostin. This led to a significant increase in proliferation with the highest proliferative effect at a periostin concentration of $10 \mathrm{ng} / \mathrm{mL}$ (Figure 9C). Again, we tried to complete this finding by ex vivo data; therefore, we scored the histology reports of $L N$ patients $(n=20)$ for mesangial proliferation and compared it with the periostin mRNA levels found by real-time RT-PCR. A trend, although not significant, for higher periostin levels in highly proliferative lupus nephritis was observed [periostin mRNA/GAPDH mRNA ratio in biopsies graded "no or mild proliferation" $(n=5)$ : $0.014 \pm$ 0.01; "moderate" $(n=11)$ : $0.032 \pm 0.03$; "severe" $(n=8)$ :
$0.13 \pm 0.18]$. Mechanisms that promote cell survival or prevent apoptosis are considered to promote cell proliferation. On different cell types, an antiapoptotic effect of periostin has been reported. ${ }^{26,27}$ Accordingly, addition of recombinant periostin significantly decreased the number of cells expressing activated caspase-3, a marker of apoptosis [vehicle treated: $4.5 \% \pm 2.1 \%$ of cells caspase-3 positive; periostin treated: $3.4 \% \pm 1.5 \%$ of cells caspase- 3 positive (ie, $24 \%$ reduction, $n=3, P<$ 0.05)]. These data are in line with our initial finding indicating that mesangial cells, as $\alpha$-SMA-positive glomerular cells, represent the source and may also be a target cell of glomerular periostin in diseased human renal tissue.

\section{Discussion}

Progressive kidney diseases are characterized by ECM deposition in glomeruli and tubular interstitium, vascular rarefaction, inflammatory cell infiltrate, and nephron loss. Matricellular proteins are known to be important regulators of fibrosis, angiogenesis, and cell-matrix interaction in different tissues, including the injured kidney. In healthy kidneys, their expression is low. As such, they became interesting candidates for therapeutic interventions in renal diseases. ${ }^{8,10}$ However, the specific role of each matricellular protein in the human kidney has still to be defined. Unexpectedly, we found recently a constitutive expression of the matricellular protein periostin in healthy human glomeruli. ${ }^{11}$ This prompted us to study the expression of periostin in different glomerulopathies.

Periostin is currently discussed as a major player in organ fibrosis but is also a critical component of mechanically challenged biological structures such as cardiac valves, annuli, and bone. It was initially isolated as an osteoblast-specific factor that functions as a cell adhesion molecule for preosteoblasts and is thought to be involved in osteoblast recruitment, attachment, and spreading. ${ }^{28}$ Periostin was found to be highly expressed in the embryonic periosteum, periodontal ligament, and the developing mouse heart during valve formation. ${ }^{29,30}$ Furthermore, under pathological conditions, periostin expression is high during wound healing and in malignant diseases. ${ }^{2}$ Knockout of the periostin gene in mice led to growth retardation and skeletal defects in terms of a periodontal disease-like phenotype and severe incisor enamel defects. ${ }^{30,31}$ About $14 \%$ of these mice died within 2 to 3 weeks after birth as the result of cardiovascular malformations caused by large acellular deposits of ECM in the valves. ${ }^{30}$ After myocardial infarction, cardiac healing is impaired in periostin-deficient mice, caused by a reduction of $\alpha$-SMA-positive cells, impaired collagen fibril formation, and finally, cardiac rupture. ${ }^{32}$ Interestingly, mice surviving without ventricular rupture show less cardiac fibrosis and better ventricular performance. ${ }^{33}$ Local application of periostin to postischemic myocardium improved also ventricular remodeling and reduced fibrosis. ${ }^{34}$

According to our knowledge, this report is the first detailed evaluation of periostin in normal kidneys and 
acquired nephropathies with interstitial fibrosis, whereas previous research on fibrotic conditions focused on myocardial fibrosis and remodeling. ${ }^{35}$ Regarding the kidney, a previous report described higher expression of periostin mRNA in cultured human autosomal dominant polycystic kidney disease cyst epithelial cells compared to normal human kidney cells. ${ }^{19}$ Periostin was localized to cyst walls in autosomal dominant polycystic kidney disease kidneys, and in vitro studies indicated that periostin increases proliferation of cyst epithelial cells via $\alpha_{v}$-integrin signaling.

Consistent with our data, the tubulointerstitial compartment of healthy kidneys showed no periostin expression in this study, where no results on the glomerular compartment were reported. Also in concordance with our data, the main positivity in diseased kidneys was found in the extracellular matrix. Wallace et $\mathrm{al}^{19}$ indicated in their report that periostin was also produced by epithelial cells of cysts in autosomal dominant polycystic kidney disease. Such epithelial positivity was not observed in our study on acquired nephropathies, where $\alpha$-SMA-positive cells were found in close proximity to periostin-positive ECM. This appears to be consistent with findings on postischemic myocardium, where fibroblasts are the main source of extracellular periostin. ${ }^{32}$ Similarly, invasion of $\alpha$-SMApositive myofibroblasts correlated with the accumulation of periostin in dermal wounds, ${ }^{36}$ and for diseased heart valves, a coexpression of periostin with $\alpha$-SMA, vimentin, and CD14 was reported. ${ }^{37}$

In healthy human kidneys, the constitutive intraglomerular periostin expression may well originate from mesangial cells. The positivity along the Bowman's capsule could derive from parietal epithelial cells, but this cannot be concluded from the current data. We speculate that in the healthy kidney, glomerular periostin has structural properties like those discussed in heart valves and may be involved in the configuration and stabilization of the vascular pole, glomerular tuft, and Bowman's capsule. These structures are of specific relevance to stabilize the glomerular architecture during capillary circulation and may therefore make use of molecular mechanisms also involved in heart valve architecture. There, periostin seems to be essential for structural integrity during mechanical stress, potentially involving a constant remodeling of the specific tissue and ECM. ${ }^{38,39}$ However, further studies are required to address this issue in the renal glomerulus.

The de novo periostin expression in the tubular interstitium derives most likely from myofibroblasts as described in postischemic myocardium or diseased heart valves. Migration and proliferation of aortic smooth muscle cells were influenced by both periostin production per se, as well as through signaling via integrin and focal adhesion kinase. ${ }^{40}$ This again is consistent with the dosedependent TGF $\beta 1$-induced induction of periostin in mesangial cells, a cell type also showing a proliferative response to external periostin. Like other secreted ECM proteins, periostin is found in fibrotic areas and interacts with ECM molecules such as collagens I and V, as well as fibronectin, known to be induced also in renal interstitial fibrosis and glomerulosclerosis. ${ }^{41-43}$ Recently, it was shown that periostin also supports bone morphogenic protein-1 (BMP1)-mediated activation of lysyl oxidase (LOX), ${ }^{44}$ an enzyme catalyzing covalent cross-linking of collagen fibrils. LOX, together with the related family member LOX-like 2 (LOXL2), has been shown to be involved in glomerulosclerosis and renal interstitial fibrosis. ${ }^{41,43}$ In addition, periostin is a ligand for cellular receptors such as integrin $\alpha_{v} \beta_{3}, \alpha_{v} \beta_{5}$, and $\alpha_{4} \beta_{6}$. In part, these receptors and the integrin-linked kinase have already been functionally linked to the development of glomerular diseases and proteinuria. ${ }^{45-47}$ We speculate that periostin in progressive renal disease is also involved in profibrotic cellular recruitment, and stimulation of ECM production and fibrosis, as is demonstrated in cardiac damage. ${ }^{33,48}$ Future interventional studies will show the significance of periostin for interstitial fibrosis and glomerulosclerosis.

In summary, periostin -in contrast to most other matricellular molecules-is constitutively expressed in healthy human glomeruli. Its expression is strikingly increased in glomeruli of patients with progressive proteinuric disease. In patients with loss of renal function and interstitial fibrosis, de novo expression of periostin is also found in the tubular interstitium. The expression in both compartments significantly correlates with reduction of glomerular filtration rate. Ex vivo and in vitro studies indicate that in the glomeruli, mesangial cells produce periostin, which can be induced by TGF $\beta 1$. As in the heart, periostin might be involved in the structural integrity of mechanically challenged structures such as the glomerular tuft and vascular pole. The strong induction of periostin in nephropathies suggests that this molecule plays a central role in renal damage and, potentially, in remodeling, similar to its function in cardiac fibrosis and healing.

\section{Acknowledgments}

We thank all participating centers of the European Renal cDNA Bank-Kröner-Fresenius biopsy bank (ERCB-KFB) and their patients for their cooperation. We also thank Ilka Edenhofer and Stefanie Gaiser for excellent technical assistance.

Active members at the time of the study are as follows: Clemens David Cohen, Holger Schmid, Michael Fischereder, Lutz Weber, Matthias Kretzler, Detlef Schlöndorff (Munich/Zurich/Ann Arbor/New York); Jean Daniel Sraer, Pierre Ronco (Paris); Maria Pia Rastaldi, Giuseppe D'Amico (Milano); Peter Doran, Hugh Brady (Dublin); Detlev Mönks, Christoph Wanner (Würzburg); Andrew Rees (Aberdeen and Vienna); Frank Strutz, Gerhard Anton Müller (Göttingen); Peter Mertens, Jürgen Floege (Aachen); Norbert Braun, Teut Risler( Tübingen); Loreto Gesualdo, Francesco Paolo Schena (Bari); Jens Gerth, Gunter Wolf (Jena); Rainer Oberbauer, Dontscho Kerjaschki (Vienna); Bernhard Banas, Bernhard Krämer (Regensburg); Moin Saleem (Bristol); Rudolf Wüthrich (Zurich); Walter Samtleben (Munich); Harm Peters, Hans-Hellmut Neumayer (Berlin); Mohamed Daha (Leiden); Katrin Ivens, Bernd Grabensee (Düsseldorf); Francisco Mampaso (Madrid); Jun Oh, Franz Schaefer, Martin Zeier, Hermann-Joseph 
Gröne (Heidelberg); Peter Gross (Dresden); Giancarlo Tonolo (Sassari); Vladimir Tesar (Prague); Harald Rupprecht (Bayreuth); Hermann Pavenstädt (Münster); HansPeter Marti (Bern); and Peter Mertens (Magdeburg).

\section{References}

1. Bornstein $\mathrm{P}$, Sage EH: Matricellular proteins: extracellular modulators of cell function. Curr Opin Cell Biol 2002, 14:608-616

2. Hamilton DW: Functional role of periostin in development and wound repair: implications for connective tissue disease. J Cell Commun Signal 2008, 2:9-17

3. Chiodoni C, Colombo MP, Sangaletti S: Matricellular proteins: from homeostasis to inflammation, cancer, and metastasis. Cancer Metastasis Rev 2010, 29:295-307

4. Llera AS, Girotti MR, Benedetti LG, Podhajcer OL: Matricellular proteins and inflammatory cells: a task force to promote or defeat cancer? Cytokine Growth Factor Rev 2010, 21:67-76

5. Ruan K, Bao S, Ouyang G: The multifaceted role of periostin in tumorigenesis. Cell Mol Life Sci 2009, 66:2219-2230

6. Hudkins KL, Giachelli CM, Eitner F, Couser WG, Johnson RJ, Alpers CE: Osteopontin expression in human crescentic glomerulonephritis. Kidney Int 2000, 57:105-116

7. Taneda S, Pippin JW, Sage EH, Hudkins KL, Takeuchi Y, Couser WG, Alpers CE: Amelioration of diabetic nephropathy in SPARC-null mice. J Am Soc Nephrol 2003, 14:968-980

8. Hugo C, Daniel C: Thrombospondin in renal disease. Nephron Exp Nephrol 2009, 111:e61-e66

9. Mizobuchi M, Towler D, Slatopolsky E: Vascular calcification: the killer of patients with chronic kidney disease. J Am Soc Nephrol 2009, 20:1453-1464

10. Phanish MK, Winn SK, Dockrell ME: Connective tissue growth factor(CTGF. CCN2): a marker, mediator and therapeutic target for renal fibrosis. Nephron Exp Nephrol 2010, 114:e83-e92

11. Lindenmeyer MT, Eichinger F, Sen K, Anders HJ, Edenhofer I, Mattinzoli D, Kretzler M, Rastaldi MP, Cohen CD: Systematic analysis of a novel human renal glomerulus-enriched gene expression dataset. PLoS One 2010, 5:e11545

12. Cohen CD, Frach K, Schlondorff D, Kretzler M: Quantitative gene expression analysis in renal biopsies: a novel protocol for a highthroughput multicenter application. Kidney Int 2002, 61:133-140

13. Cohen CD, Klingenhoff A, Boucherot A, Nitsche A, Henger A, Brunner B, Schmid H, Merkle M, Saleem MA, Koller KP, Werner T, Grone HJ, Nelson PJ, Kretzler M: Comparative promoter analysis allows de novo identification of specialized cell junction-associated proteins, Proc Natl Acad Sci U S A 2006, 103:5682-5687

14. Cohen CD, Lindenmeyer MT, Eichinger F, Hahn A, Seifert M, Moll AG, Schmid H, Kiss E, Grone E, Grone HJ, Kretzler M, Werner T, Nelson PJ: Improved elucidation of biological processes linked to diabetic nephropathy by single probe-based microarray data analysis. PLoS One 2008, 3:e2937

15. Tusher VG, Tibshirani R, Chu G: Significance analysis of microarrays applied to the ionizing radiation response, Proc Natl Acad Sci U S A 2001, 98:5116-5121

16. Segerer S, Cui Y, Eitner F, Goodpaster T, Hudkins KL, Mack M, Cartron JP, Colin Y, Schlondorff D, Alpers CE: Expression of chemokines and chemokine receptors during human renal transplant rejection. Am J Kidney Dis 2001, 37:518-531

17. Jedlicka J, Soleiman A, Draganovici D, Mandelbaum J, Ziegler U, Regele H, Wuthrich RP, Gross O, Anders HJ, Segerer S: Interstitial inflammation in Alport syndrome. Hum Pathol 2010, 41:582-593

18. Soltermann A, Tischler V, Arbogast S, Braun J, Probst-Hensch N, Weder W, Moch H, Kristiansen G: Prognostic significance of epithelial-mesenchymal and mesenchymal-epithelial transition protein expression in nonsmall cell lung cancer. Clin Cancer Res 2008, 14:7430-7437

19. Wallace DP, Quante MT, Reif GA, Nivens E, Ahmed F, Hempson SJ, Blanco G, Yamaguchi T: Periostin induces proliferation of human autosomal dominant polycystic kidney cells through alphaV-integrin receptor. Am J Physiol Renal Physiol 2008, 295:F1463-1471

20. Banas B, Luckow B, Moller M, Klier C, Nelson PJ, Schadde E, Brigl M, Halevy D, Holthofer H, Reinhart B, Schlondorff D: Chemokine and chemokine receptor expression in a novel human mesangial cell line. J Am Soc Nephrol 1999, 10:2314-2322

21. Wolf G, Aberle S, Thaiss F, Nelson PJ, Krensky AM, Neilson EG, Stahl RA: TNF alpha induces expression of the chemoattractant cytokine RANTES in cultured mouse mesangial cells. Kidney Int 1993, 44:795-804

22. Bhavnani SK, Eichinger F, Martini S, Saxman P, Jagadish HV, Kretzler M: Network analysis of genes regulated in renal diseases: implications for a molecular-based classification. BMC Bioinformatics 2009, 10 (Suppl 9):S3

23. Conway SJ, Molkentin JD: Periostin as a heterofunctional regulator of cardiac development and disease. Curr Genomics 2008, 9:548-555

24. Kikuchi $Y$, Kashima TG, Nishiyama T, Shimazu K, Morishita Y, Shimazaki M, Kii I, Horie H, Nagai H, Kudo A, Fukayama M: Periostin is expressed in pericryptal fibroblasts and cancer-associated fibroblasts in the colon. J Histochem Cytochem 2008, 56:753-764

25. Schlondorff D, Banas B: The mesangial cell revisited: no cell is an island. J Am Soc Nephrol 2009, 20:1179-1187

26. Bao S, Ouyang G, Bai X, Huang Z, Ma C, Liu M, Shao R, Anderson RM, Rich JN, Wang XF: Periostin potently promotes metastatic growth of colon cancer by augmenting cell survival via the Akt/PKB pathway. Cancer Cell 2004, 5:329-339

27. Zhu M, Fejzo MS, Anderson L, Dering J, Ginther C, Ramos L, Gasson JC, Karlan BY, Slamon DJ: Periostin promotes ovarian cancer angiogenesis and metastasis. Gynecol Oncol 2010, 119:337-344

28. Takeshita S, Kikuno R, Tezuka K, Amann E: Osteoblast-specific factor 2: cloning of a putative bone adhesion protein with homology with the insect protein fasciclin I. Biochem J 1993, 294 (Pt 1):271-278

29. Kruzynska-Frejtag A, Machnicki M, Rogers R, Markwald RR, Conway SJ: Periostin (an osteoblast-specific factor) is expressed within the embryonic mouse heart during valve formation. Mech Dev 2001, 103:183-188

30. Rios H, Koushik SV, Wang H, Wang J, Zhou HM, Lindsley A, Rogers R, Chen Z, Maeda M, Kruzynska-Frejtag A, Feng JQ, Conway SJ: periostin null mice exhibit dwarfism, incisor enamel defects, and an early-onset periodontal disease-like phenotype. Mol Cell Biol 2005, 25:11131-11144

31. Kii I, Amizuka N, Minqi L, Kitajima S, Saga Y, Kudo A: Periostin is an extracellular matrix protein required for eruption of incisors in mice. Biochem Biophys Res Commun 2006, 342:766-772

32. Shimazaki M, Nakamura K, Kii I, Kashima T, Amizuka N, Li M, Saito M, Fukuda K, Nishiyama T, Kitajima S, Saga Y, Fukayama M, Sata M, Kudo A: Periostin is essential for cardiac healing after acute myocardial infarction. J Exp Med 2008, 205:295-303

33. Oka T, Xu J, Kaiser RA, Melendez J, Hambleton M, Sargent MA, Lorts A, Brunskill EW, Dorn GW 2nd, Conway SJ, Aronow BJ, Robbins J, Molkentin JD: Genetic manipulation of periostin expression reveals a role in cardiac hypertrophy and ventricular remodeling. Circ Res 2007, 101:313-321

34. Kuhn B, del Monte F, Hajjar RJ, Chang YS, Lebeche D, Arab S, Keating MT: Periostin induces proliferation of differentiated cardiomyocytes and promotes cardiac repair. Nat Med 2007, 13:962-969

35. Dorn GW 2nd: Periostin and myocardial repair, regeneration, and recovery. N Engl J Med 2007, 357:1552-1554

36. Jackson-Boeters L, Wen W, Hamilton DW: Periostin localizes to cells in normal skin, but is associated with the extracellular matrix during wound repair. J Cell Commun Signal 2009, 3:125-133

37. Hakuno D, Kimura N, Yoshioka M, Mukai M, Kimura T, Okada Y, Yozu R, Shukunami C, Hiraki Y, Kudo A, Ogawa S, Fukuda K: Periostin advances atherosclerotic and rheumatic cardiac valve degeneration by inducing angiogenesis and MMP production in humans and rodents. J Clin Invest 2010, 120:2292-2306

38. Snider $\mathrm{P}$, Hinton RB, Moreno-Rodriguez RA, Wang J, Rogers R, Lindsley A, Li F, Ingram DA, Menick D, Field L, Firulli AB, Molkentin JD, Markwald R, Conway SJ: Periostin is required for maturation and extracellular matrix stabilization of noncardiomyocyte lineages of the heart. Circ Res 2008, 102:752-760

39. Norris RA, Moreno-Rodriguez RA, Sugi Y, Hoffman S, Amos J, Hart MM, Potts JD, Goodwin RL, Markwald RR: Periostin regulates atrioventricular valve maturation. Dev Biol 2008, 316:200-213

40. Li G, Jin R, Norris RA, Zhang L, Yu S, Wu F, Markwald RR, Nanda A, Conway SJ, Smyth SS, Granger DN: Periostin mediates vascular smooth muscle cell migration through the integrins alphavbeta3 and alphavbeta5 and focal adhesion kinase (FAK) pathway. Atherosclerosis 2010, 208:358-365

41. Higgins DF, Kimura K, Bernhardt WM, Shrimanker N, Akai Y, Hohenstein B, Saito Y, Johnson RS, Kretzler M, Cohen CD, Eckardt KU, Iwano M, Haase 
VH: Hypoxia promotes fibrogenesis in vivo via HIF-1 stimulation of epithelial-to-mesenchymal transition. J Clin Invest 2007, 117:3810-3820

42. Lindenmeyer MT, Kretzler M, Boucherot A, Berra S, Yasuda Y, Henger A, Eichinger F, Gaiser S, Schmid H, Rastaldi MP, Schrier RW, Schlondorff D, Cohen CD: Interstitial vascular rarefaction and reduced VEGF-A expression in human diabetic nephropathy. J Am Soc Nephrol 2007, 18:1765-1776

43. Neusser MA, Lindenmeyer MT, Moll AG, Segerer S, Edenhofer I, Sen K, Stiehl DP, Kretzler M, Grone HJ, Schlondorff D, Cohen CD: Human nephrosclerosis triggers a hypoxia-related glomerulopathy. Am J Pathol 2010, 176:594-607

44. Maruhashi T, Kii I, Saito M, Kudo A: Interaction between periostin and BMP-1 promotes proteolytic activation of lysyl oxidase. J Biol Chem 2010, 285:13294-13303

45. Kretzler M, Teixeira VP, Unschuld PG, Cohen CD, Wanke R, Edenhofer I, Mundel P, Schlondorff D, Holthofer H: Integrin-linked kinase as a candidate downstream effector in proteinuria. FASEB $\mathrm{J} 2001$, 15:1843-1845

46. Wei C, Moller CC, Altintas MM, Li J, Schwarz K, Zacchigna S, Xie L, Henger A, Schmid H, Rastaldi MP, Cowan P, Kretzler M, Parrilla R, Bendayan M, Gupta V, Nikolic B, Kalluri R, Carmeliet P, Mundel P, Reiser J: Modification of kidney barrier function by the urokinase receptor. Nat Med 2008, 14:55-63

47. Kang YS, Li Y, Dai C, Kiss LP, Wu C, Liu Y: Inhibition of integrin-linked kinase blocks podocyte epithelial-mesenchymal transition and ameliorates proteinuria. Kidney Int 2010, 78:363-373

48. Teekakirikul $P$, Eminaga S, Toka O, Alcalai R, Wang L, Wakimoto $H$, Nayor M, Konno T, Gorham JM, Wolf CM, Kim JB, Schmitt JP, Molkentin JD, Norris RA, Tager AM, Hoffman SR, Markwald RR, Seidman CE, Seidman JG: Cardiac fibrosis in mice with hypertrophic cardiomyopathy is mediated by non-myocyte proliferation and requires Tgf-beta. J Clin Invest 2010, 120:3520-3529 